\title{
The IMPACT OF THE CONVENTION ON THE RIGHTS OF PERSONS WITH DISABILITIES ON CANADIAN JURISPRUDENCE: THE CASE OF LEOBRERA V. CANADA
}

\begin{abstract}
RAVI MALHOTRA*
This article traces the historical and continuing exclusion of people with disabilities found in Canada's immigration law and policy. It highlights how an immigration policy focused on economic growth and avoiding health care costs can have devastating effects on individuals and the families of children with disabilities. Using the case of Leobrera v. Canada as a case study, the author looks to the Convention on the Rights of Persons with Disabilities as an international instrument which could help change Canada's exclusionary policies.
\end{abstract}

\section{TABLE OF Contents}

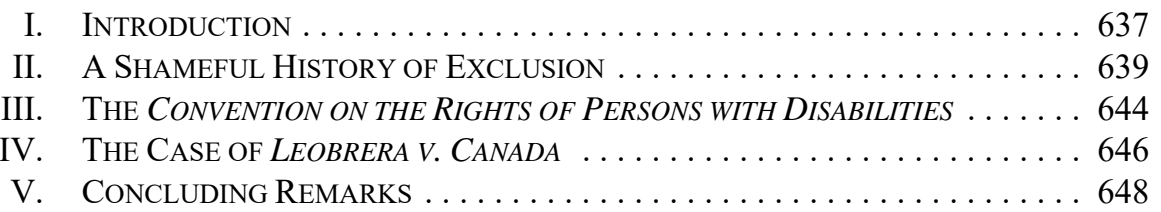

\section{INTRODUCTION}

People with disabilities have been historically regarded as undesirable immigrants because they have been perceived as a financial burden to the state. This is particularly the case amongst those who regard immigration policy as an exercise in attracting those most likely to succeed in the labour market and contribute taxes to the state. Many countries consequently have enacted in place explicit statutory or regulatory mechanisms to bar people with disabilities from obtaining immigration status. ${ }^{1}$ This often has a particularly negative effect on children with disabilities who are denied entry, along with their families, solely because of their impairments.

Recently, widespread media coverage was accorded to the case of a York University professor from Costa Rica, Felipe Montoya, who was denied permanent residency status in Canada solely because his son has Down syndrome. ${ }^{2}$ In Canada, section 38(1) of the Immigration and Refugee Protection Act states that a foreign national is inadmissible on health grounds where she or he is likely to be a danger to public health, likely to be a danger on public safety grounds, or "might reasonably be expected to cause excessive demand on

Associate Professor, Faculty of Law, Common Law Section, University of Ottawa. I would like to acknowledge and thank Colleen Flood and Lorian Hardcastle for their work in organizing this issue. See Yahya El-Lahib \& Samantha Wehbi, "Immigration and Disability: Ableism in the Policies of the Canadian State" (2011) 55:1 Intl Social Work 95 (analyzing disability discrimination in the Canadian context); Nilan G Yu, "Ableism and Economic Rationalism in Australian Immigration" (2014) 23:3 Intl J Social Welfare 254 (analyzing disability discrimination in the Australian immigration context); K Soldatic \& L Fiske, "Bodies 'Locked Up': Intersections of Disability and Race in Australian Immigration" (2009) 24:3 Disability \& Society 289.

$2 \quad$ "York University Prof Denied Permanent Residency Over Son's Down Syndrome," CBC News (14 March 2016), online: <www.cbc.ca/news/canada/toronto/programs/metromorning/costa-rica-downsyndrome-1.3489120>; Mark C Weber, "The Bigger Barrier to Immigration," Winnipeg Free Press (11 May 2016) A7. 
health or social services." ${ }^{33}$ Immigrants with disabilities have been deemed medically inadmissible under this provision. Even when this is not the case, informal perceptions and attitudes may serve as profound barriers for immigrants with disabilities. Although Canadian immigration policy has been historically plagued by systemic racism, the continued exclusion of people with disabilities under the guise of medical inadmissibility reflects in part an increasingly marked shift in public policy to valuing migrants based on their predicted economic contribution or human capital. ${ }^{4}$ As the neo-liberal paradigm has become more prominent in shaping how state actors strategically select immigrants to advance macroeconomic goals, these pernicious attitudes will only grow. Challenging these assumptions have been domestic protections such as the equality provision contained in section 15 of the Canadian Charter of Rights and Freedoms $s^{5}$ and international human rights instruments such as the landmark Convention on the Rights of Persons with Disabilities, ${ }^{6}$ as well as the passion and activism of disability rights advocates and their allies on the ground. ${ }^{7}$ Undergirding their perspective is the deeply held belief in the merits of the social model of disablement. This stands for the proposition that it is the structural barriers in society that are the primary problem facing people with disabilities. In other words, one has to shift away from exclusively medical intervention such as surgery to remedying systemic barriers that exclude people with physical and mental disabilities from participating in activities of daily living. ${ }^{8}$

In this article, I explore the implications of the CRPD for Canadian jurisprudence through the prism of a single and rather tragic case, Saporsantos Leobrera v. Canada (Citizenship and Immigration). ${ }^{9}$ In Part II, I discuss the history of Canadian immigration policy and the legacy of exclusion of people with disabilities. In Part III, I discuss the potential of the CRPD to transform both the law and attitudes with respect to people with disabilities. In Part IV, I discuss the Federal Court decision in Leobrera, which held that an adult child with a disability remains an adult for the purposes of section 25 of IRPA, the Convention on the Rights of the Child, ${ }^{10}$ and the CRPD. In Part V, I offer brief conclusions.

\footnotetext{
SC 2001, c 27, s 38(1)(c) [IRPA].

Yasmeen Abu-Laban, "Welcome/Stay Out: The Contradiction of Canadian Integration and Immigration Policies at the Millennium" (1998) 30:3 Can Ethnic Studies 190; Gillian Creese et al, "The 'Flexible' Immigrant? Human Capital Discourse, the Family Household and Labour Market Strategies" (2008) 9:3 J Intl Migration \& Integration 269. See also Peter S Li, Destination Canada: Immigration Debates and Issues (Oxford: Oxford University Press, 2003) at 80 (noting increased relative weight of the economic class in recent years).

Part I of the Constitution Act, 1982, being Schedule B to the Canada Act 1982 (UK), 1982, c 11 [Charter].

613 December 2006, 2515 UNTS 3 (entered into force 3 May 2008) [CRPD].

7 The literature on the CRPD in Canadian law reviews is to date relatively small. But see $\mathrm{H}$ Archibald Kaiser, "The Convention on the Rights of Persons with Disabilities: Beginning to Examine the Implications for Canadian Lawyers' Professional Responsibilities" (2012) 20: 2 Health L Rev 26; Linda C Reif, "Ombudsman Institutions and Article 33(2) of the United Nations Convention on the Rights of Persons with Disabilities" (2014) 65 UNBLJ 213; Ravi Malhotra \& Robin F Hansen, "The United Nations Convention on the Rights of Persons with Disabilities and Its Implications for the Equality Rights of Canadians with Disabilities: The Case of Education" (2011) 29:1 Windsor YB Access Just 73. For an important intervention on Article 33, see Gauthier de Beco, ed, Article 33 of the UN Convention on the Rights of Persons with Disabilities: National Structures for the Implementation and Monitoring of the Convention (Leiden: Martinus Nijhoff, 2013). This article will for the most part not discuss the section 15 jurisprudence in the interests of space. The literature on this topic is vast. The canonical reference is Michael Oliver, The Politics of Disablement (London: Macmillan Press, 1990). For a more recent treatment, see Pamela Block et al, eds, Occupying Disability: Critical Approaches to Community, Justice, and Decolonizing Disability (New York: Springer, 2016). 


\section{A Shameful History Of ExClusion}

The Canadian state has had a long history of excluding people with both physical impairments and mental conditions as potential immigrants. This should be situated in the context of its long history of white settler colonialism and racist exclusion of various groups at different times, including Chinese Canadians, South Asians, and many others. ${ }^{11}$ Historically, it was not uncommon for Canadian medical evaluators abroad to simply prohibit all immigration applicants with any kind of real or perceived impairment, without demonstrating any impact with respect to employment or functioning in activities of daily living. Typically, little in-depth physical examination of the applicant was performed. ${ }^{12}$ In some cases, the evidence indicates that this wide net captured individuals who had no disabilities whatsoever. ${ }^{13}$ Chadha has documented the historic exclusion of people with mental conditions, dating back to pre-Confederation times. She notes how legislation as early as the 1850 s mandated immigration inspectors to bar entry to those deemed to be deaf, dumb, blind, an idiot, or a lunatic. ${ }^{14}$ It is also important to bear in mind that the distinction between mental and physical disabilities was less well understood in the nineteenth century than in contemporary times. As well, the distinction between people with psychiatric conditions (or "lunatics" in the jargon of the day) and intellectual disabilities (or "idiots" and later the "retarded") was also sometimes blurred. This frequently led to the wrongful exclusion of people whose impairments were not well understood at the time.

Canada's first major post-Confederation legislative provision with respect to immigration was The Immigration Act of $1866 .{ }^{15}$ This statute authorized the imposition of significant fines on ship operators who transported into Canadian ports people with physical, intellectual, and psychiatric conditions. ${ }^{16}$ Provincial laws also prohibited philanthropic societies or individuals from bringing into the province children under the age of eighteen "of 'defective' intellect or physique." $" 17$ This development paralleled the dramatic growth of institutions and orphanages in the nineteenth century to exclude people with psychiatric and intellectual disabilities from life in the community. ${ }^{18}$ This exclusion in turn reflected the growing popularity of eugenic ideas that associated physical and intellectual impairments with

For an illuminating effort to address white settler colonialism from a postcolonial perspective, see Karen Soldatic, "Postcolonial Reproductions: Disability, Indigeneity, and the Formation of the White Masculine Settler State of Australia" (2015) 21:1 Social Identities 53.

12 Valentina Capurri, Canadian Public Discourse Around Issues of Inadmissibility for Potential Immigrants with Diseases and/or Disabilities 1902-2002 (PhD Dissertation, York University, Graduate Program in History, 2010) at 254-55 [Capurri, Canadian]. See also Valentina Capurri, "The Medical Admissibility Problem vis-à-vis The Charter of Rights and Freedoms" (2012) 16:1 Left History 91.

13 Capurri, Canadian, ibid at 255-56. In Australia, Soldatic and Fiske have documented, well into the 21s century, the bizarre problem of racialized people with psychiatric or intellectual disabilities who have been wrongly deported even where they are legally Australian residents or citizens due to a combination of racial stereotyping, systemic ableism, and incompetent officials: Soldatic \& Fiske, supra note 1 at 291-92.

14 Ena Chadha, “'Mentally Defectives' Not Welcome: Mental Disability in Canadian Immigration Law, 1859-1927” (2008) 28:1 Disability Studies Q, online:<dsq-sds.org/article/view/67/67>. See also Rose Voyvodic, "Into the Wasteland: Applying Equality Principles to Medical Inadmissibility in Canadian Immigration Law" (2001) 16 J L \& Soc Pol'y 115 at 131.

RSC 1886, c 65.

Chadha, supra note 14.

Ibid, citing Penny L Richards, "Points of Entry: Disability and the Historical Geography of Immigration" (2004) 24:3 Disability Studies Q, online: <dsq-sds.org/article/view/505/682>.

Chadha, ibid. There is a massive amount of literature on this topic. See e.g. Geoffrey Reaume, Remembrance of Patients Past: Patient Life at the Toronto Hospital for the Insane, 1870-1940 (Toronto: University of Toronto Press, 1997). 
problems of morality and sought to cleanse the population of those regarded as undesirable including racial minorities who were not deemed suitable for Canadian society and those with sexual identities regarded as deviant such as gays, lesbians, bisexuals, and transsexuals. ${ }^{19}$ Prominent Canadians such as the social justice advocate, parliamentarian, and future Cooperative Commonwealth Federation (CCF) leader J.S. Woodsworth notoriously held eugenic views. ${ }^{20}$ In the case of middle class immigrants with disabilities, the government often relied on the argument of precedent, suggesting that individual exceptions could not be tolerated because they would open the floodgates. ${ }^{21}$

It should be noted, however, that even in the early twentieth century, there were always some parliamentarians and other policy leaders who publicly opposed the exclusion of people with disabilities from Canadian society. While they did not necessarily represent the majority sentiment in the country, their statements are interesting as they provide insight into their reasoning and the analytical distinctions at play. For instance, some parliamentarians strongly objected to the exclusion of immigrant families where one child (in an era where large families were commonplace) had an impairment, and the family was clearly able and willing to support the child with the impairment. Similarly, some parliamentarians, in a pre-Charter era, objected to the deportation of immigrants who acquired impairments while working in Canada and awaiting citizenship as violating principles of natural justice. ${ }^{22}$ The discourse of productivity dominant in the early twentieth century then was tempered by other discursive narratives, including preserving family cohesion and natural justice for long-term residents. This was embodied in exceptions in immigration legislation issued in 1886, and repeated in the 1906 amendments, that allowed individuals with disabilities to immigrate where either they could demonstrate the capacity to engage in a profession or trade, or alternatively a family member agreed to provide permanent support. ${ }^{23}$ Unfortunately, the rise in popularity of eugenics discourse, which was especially prevalent in the institutionalization of sterilization of people with disabilities in Alberta and British Columbia, led to a tightening of the regulations barring people with disabilities over the course of the early twentieth century. $^{24}$

Three factors can be identified as leading toward a gradual relaxation of the productivity discourse that excluded people with disabilities after the Second World War. First, the disclosure of the horrors of the Nazi Holocaust made eugenics unpopular in the public sphere. Second, disabled veterans returning from service in the Second World War demanded reintegration, including meaningful employment and adequate health services, into Canadian society. Finally, the role of the state changed to one of managing the redistribution of wealth History, 1700-2010” in Susan Burch \& Michael Rembis, eds, Disability Histories (Urbana: University of Illinois Press, 2014).

20 See Erica Dyck, Facing Eugenics: Reproduction, Sterilization, and the Politics of Choice (Toronto: University of Toronto Press, 2013) at 41-42 (documenting Woodsworth's eugenic views prior to World War I).

Capurri, Canadian, supra note 12 at 107

Ibid at 90-92.

Hilewitz $v$ Canada (Minister of Citizenship and Immigration); De Jong $v$ Canada (Minister of Citizenship and Immigration), 2005 SCC 57, [2005] 2 SCR 706 at paras 42-45 [Hilewitz and De Jong], rev'g 2003 FCA 420, [2004] 1 FCR 696 [Hilewitz FCA] and 2003 FCA 422, 315 NR 59 [De Jong FCA].

24 Immigration Act, RSC 1927, c 93, s 3. See Hilewitz and De Jong, ibid at paras 45-46. Unfortunately, Alberta did not repeal its sterilization legislation until 1972: see Dyck, supra note 20 at 4. 
as the welfare state expanded amidst the prosperity of the post-War boom. ${ }^{25}$ Together, these three factors made an emphasis on productivity alone outdated. However, people with disabilities continued to be excluded if immigration officials determined that they were an undue burden on the welfare state. The notion that people with disabilities, whether in or outside of the traditional labour market, were essentially inauthentic workers remained prevalent. $^{26}$

With the coming into force of section 15 of the Charter in 1985, the legal landscape changed as equality was enshrined in Canada's constitutional framework. Prospective immigrants with disabilities began to make arguments that these exclusionary policies violated their Charter rights. ${ }^{27}$ In Chesters v. Canada, ${ }^{28}$ the Federal Court held that a German citizen was not entitled to a declaration that the medical inadmissibility provision contained in section 19(1) of the then Immigration Act violated sections 7 and 15 of the Charter. Angela Chesters was married to a Canadian citizen she met in Germany who subsequently returned to Canada. She was, however, deemed to be medically inadmissible because of her diagnosis of multiple sclerosis which required her to use a wheelchair and resulted in incontinence. ${ }^{29}$ Instead, she was only able to remain in Canada on a highly precarious Minister's Permit, which had to be renewed annually and which denied her access to the full suite of services available to permanent residents notwithstanding her marriage to a Canadian citizen. ${ }^{30}$ The immigration authorities concluded that the progressive nature of multiple sclerosis would inexorably lead to an excessive demand on health and social services pursuant to the then operative section 19(1)(a)(ii) of the Immigration Act. ${ }^{31}$

On judicial review, the Federal Court upheld the decision. The Court concluded that the excessive demand standard did not create an adverse impact on people with disabilities, particularly given that the context before the Court was immigration law. In this domain, the Court granted significant deference to the government to craft appropriate regulatory standards for entry of non-citizens as it saw fit. The Court emphasized entry to Canada for non-residents was a privilege, not a right. ${ }^{32}$ In other words, it seems that the Court places a lower standard on human rights in the context of immigration law, which raises troubling questions about democracy and the meaning of citizenship in a globalized world. It should also be noted that the Court rejected the adverse impact argument on the ground that insufficient contextual evidence was proffered by legal counsel, notwithstanding the

Capurri, Canadian, supra note 12 at 108-11. On the Nazi eugenics program to exterminate people with disabilities, see Marta Russell, Beyond Ramps: Disability at the End of the Social Contract (Monroe, Me: Common Courage Press, 1998).

26 See Sunny Taylor, "The Right Not to Work: Power and Disability" (2004) 55:10 Monthly Rev, online: $<$ monthlyreview.org/2004/03/01/the-right-not-to-work-power-and-disability/>. On the concept of authentic workers in the context of gender equality, see the canonical article Vicki Schultz, "Life's Work" (2000) 100:7 Colum L Rev 1881 at 1892. Such attitudes have even hindered refugees in accessing disability benefits. For a study of Cambodian refugees with disabilities who faced denial of social insurance benefits in the United States, see Theodore McCombs, "Post Trauma: Cambodian Refugees and Social Security's Disability Fraud Investigations" (2008) 5:2 Hastings Race \& Poverty LJ 353.

27 See Ravi Malhotra, "Disability Rights and Immigration" New Socialist Magazine 55 (February-March 2006) 4 at 4-7, online: <www.newsocialist.org/attachments/125_NewSocialist-Issue55.pdf $>$. (2002), [2003] 1 FC 361, 221 FTR 1 [Chesters].

Ibid at paras 7,18 .

Ibid at para 55. Ontario, for example, excluded holders of Ministerial Permits from its health insurance plan in the late 1990s.

Ibid at para 27. See Immigration Act, RSC 1985, c I-2 , s 19(1)(a)(ii).

Chesters, ibid at paras 83, 120 . 
submissions of noted disability rights advocate Catherine Frazee on the discriminatory effects of the law. ${ }^{33}$ Consequently, it rejected arguments that the actions of the immigration authorities violated either section 15 or section 7 of the Charter. ${ }^{34}$ This speaks to the question of how best to craft one's case to convince the Court in constitutional matters. Clearly, counsel is well-advised to marshal significant and specific expert evidence in immigration cases tailored to that particular context and may well wish to make use of the CRPD, as discussed below, where appropriate.

As I alluded to in the introduction, there has been a significant shift in the pattern of Canadian immigration flows toward a greater emphasis on economic migrants who are regarded as fueling Canada's future economic prosperity. How the intersection of wealthier prospective immigrants and disability plays out in a neo-liberal world remains an open question. These issues came to a head in Hilewitz and De Jong. ${ }^{35}$ In these two cases released jointly, the Supreme Court, by a 7-2 margin, ruled that family support ought to be considered in evaluating medical inadmissibility. The majority decision, written by Justice Abella, allowed the appeal of the prospective immigrants and held that the personal assets of families admitted under the investor class were relevant when considering whether their children, who had intellectual disabilities, constituted an excessive demand on social services. ${ }^{36}$

Hilewitz was a successful South African businessman, with a wife and two children, who qualified for permanent residency under the investor class program. This required him to have significant business experience, a net worth of at least $\$ 800,000$, and commit to making a significant investment in Canada. ${ }^{37}$ Nonetheless, despite his wealth, his application for immigration was rejected by a visa officer because of his seventeen year old son Gavin's intellectual disability, which apparently rendered him with the educational abilities of an eight year old, was deemed to constitute an excessive demand on social services. ${ }^{38}$ On judicial review, the Federal Court, in a decision by Justice Gibson, concluded that one could distinguish between health services and social services. In the case of social services, the Court concluded that it was acceptable to consider a family's personal financial resources to support a dependent with disabilities. ${ }^{39}$ In this case, the Hilewitz family was willing to fund Gavin's education at a private school suitable for his needs and had even identified such a school. ${ }^{40}$ On further appeal, the Federal Court of Appeal, speaking through Justice Evans, unanimously restored the decision of the visa officer. The Federal Court of Appeal concluded that the visa officer's risk averse approach was appropriate because it was not possible to predict the future financial health of the family, potentially creating a burden on the Canadian state should the family's circumstances change. ${ }^{41}$

Ibid at paras $118-19$.

Ibid at paras 129-31.

Supra note 23 .

Ibid at paras $70-72$.

Ibid at paras 8-9.

Ibid at para 18 .

Ibid at paras 21-23. There was a separate ground of appeal relating to procedural fairness with respect to whether the immigration officers wrongly failed to read the response of the families to the opinions of the visa officers. This ground was also successful but will not be explored further here.

$40 \quad$ Ibid at para 16.

Ibid at paras 24-26. 
De Jong was a successful Dutch dairy farmer who qualified for permanent residence under the self-employed category. A married father of six children, he planned to run a similar farm in Canada. One of his daughters, Dirkje, had an intellectual disability. However, his application was similarly rejected as constituting excessive demands on Canadian social services even though he planned to send Dirkje to a church run private school. ${ }^{42}$ De Jong sought judicial review of this decision in Federal Court. Although he was initially successful in convincing the Federal Court, the remedy of a new review by another immigration officer ordered by Justice Reed resulted in yet another decision concluding that Dirkje's needs would constitute an excessive demand. The visa officer relied on a new medical opinion that expressed concerns that the family financial situation may change in the future, potentially resulting in an excessive demand on Canadian social services. ${ }^{43}$ De Jong sought judicial review in Federal Court again. This time, Justice Pinard of the Federal Court concluded that the family's ability and willingness to pay for private school was irrelevant in determining medical inadmissibility where excessive demand on social services, not just health services, had been demonstrated. ${ }^{44}$ On further appeal, the Federal Court of Appeal, relying on its newly decided decision in Hilewitz FCA, ${ }^{45}$ upheld the decision of the Federal Court. ${ }^{46}$

The majority of the Supreme Court allowed the appeals of the families. After noting the relaxation of immigration restrictions to allow exception for people with disabilities whose families could provide financial support rather than a blanket rule of exclusion, particularly after the 1966 White Paper on Immigration, ${ }^{47}$ the Court found that the statute required individualized assessments that took into account the ability of families to contribute to social services. ${ }^{48}$ The majority of the Court concluded that the language of the statutory provision mandated an individualized assessment and that a "more likely than not" standard for evaluating a burden was required. ${ }^{49}$ In other words, a mere remote possibility that a family might default on a financial promise in the distant future was insufficient to trigger the excessive burden exclusion. While this is undoubtedly a victory, it should be noted that Hilewitz would only apply to the relatively privileged class of immigrants who qualify for the investor or self employed class. Although there has undoubtedly been a shift in these neoliberal times toward a greater emphasis on business immigrants, ${ }^{50}$ it would nevertheless still exclude significant numbers of immigrants. Furthermore, the Court's distinction between social services and health services means that a family's willingness to pay privately for medical costs would continue to remain legally irrelevant and pose a barrier for the

$42 \quad$ Ibid at paras $27-30$.

Ibid at paras $31-35$.

Ibid at para 36 .

Supra note 23.

De Jong FCA, supra note 23.

Parliament, "White Paper on Immigration: Canada Immigration Policy, 1966" by Jean Marchand in Sessional Papers, No 13A (1966).

Hilewitz and De Jong, supra note 23 at paras 44-50. But see Yasmeen Abu-Laban, "Keeping 'em Out: Gender, Race, and Class Biases in Canadian Immigration Policy" in Veronica Strong-Boag et al, eds, Painting the Maple: Essays on Race, Gender, and the Construction of Canada (Vancouver: UBC Press, 1998) 69 at 75 [Abu-Laban, "Keeping"] (noting the emphasis on economic productivity in the 1966 White Paper).

$49 \quad$ Hilewitz and De Jong, ibid at para 58.

50 See Abu-Laban, "Keeping," supra note 48 at 77-79. 
immigration of individuals such as Angela Chesters. ${ }^{51}$ Third, it should be noted that unlike the decision in Chesters, this decision was reached on the basis of statutory interpretation rather than the Charter or the invocation of international human rights instruments. In Part III, I explore one such instrument, the Convention on the Rights of Persons with Disabilities and its potential as one tool in the legal arsenal for social justice for people with disabilities.

\section{The ConVEntion on THE Rights of PERSONS With DisabiLITIES}

The CRPD was the first international human rights treaty of the twenty-first century and the eighth major international human rights treaty. The General Assembly approved an initial resolution in 2001 and the Convention text received sufficient signatures to come into force in $2008 .^{52}$ Canada ratified it during the Vancouver Winter Olympics in $2010 .^{53}$ It was the fastest negotiated UN human rights convention in history. ${ }^{54}$

The CRPD consists of some 50 articles and blends rights relating to more canonical rights such as civil liberties, traditionally articulated in the International Covenant on Civil and Political Rights, ${ }^{55}$ and supposedly newer or second generation socioeconomic rights, embodied in the International Covenant on Economic, Social and Cultural Rights. ${ }^{56}$ While the drafters made it clear that no new rights were to be created in the CRPD, it represented a political compromise that sought a broad approach to satisfy multiple constituencies. ${ }^{57}$ Some of its major provisions include article 12, which requires State Parties to recognize that people with disabilities have equal protection before the law and to empower them to engage their legal capacity as appropriate; article 14, which requires State Parties to recognize that people with disabilities have a right to liberty and security of the person; and article 18, which guarantees liberty of movement and nationality. ${ }^{58}$ The CRPD necessarily bridges the gap between civil and political rights and socioeconomic rights because transforming abstract rights for people with disabilities often involves the provision of requisite supports, which inevitably entails some socioeconomic outlay. This underscores the distinction between

$51 \quad$ See e.g. Barlagne v Canada (Citizenship and Immigration), 2010 FC 547, 367 FTR 281 (upholding the decision of an immigration officer that the schooling needs of a child with cerebral palsy constituted excessive demand for social services). Although the applicant attempted to make an equality rights claim under section 15 of the Charter, this was dismissed for both procedural failures and insufficient evidence (ibid at para 63). Eventually, after media coverage, the Quebec government agreed to issue a selection certificate for this family, see "Family with Disabled Child Can Stay in Canada," CBC News (20 April 2011), online: <www.cbc.ca/news/canada/montreal/family-with-disabled-child-can-stay-in-canada1.991459>.

52 Gerard Quinn, "A Short Guide to the United Nations Convention on the Rights of Persons with Disabilities" in Gerard Quinn \& Lisa Waddington, eds, European Yearbook of Disability Law: Volume 1 (Portland: Intersentia, 2009) 89 at 91 [Quinn, "Short"]; Stefan Tromel, "A Personal Perspective on the Drafting History of the United Nations Convention on the Rights of Persons with Disabilities" in Quinn \& Waddington, ibid, 115 at 116 .

53 "Canada Ratifies UN Treaty for Disabled Rights," CBC News (11 March 2010), online: <www.cbc.ca/ news/world/canada-ratifies-un-treaty-for-disabled-rights-1.883280>.

54 United Nations, "United Nations Convention on the Rights of Persons with Disabilities (CRPD)," Infographic (August 2015), online: <www.un.org/disabilities/documents/COP/cosp8_infographic.pdf $>$. 19 December 1966, 999 UNTS 171 (entered into force 23 March 1976).

16 December 1966, 993 UNTS 3 (entered into force 3 January 1976).

Quinn, "Short," supra note 52 at 99 . There were other dimensions to the political tensions in the drafting of the CRPD. In addition to the issue of first generation versus second generation rights, some State Parties envisioned a full-blown highly detailed Convention with very specific enumerated rights while others would have preferred a short document that would amount to a mere appendix to an existing protocol. See also Malhotra \& Hansen, supra note 7 at 79.

$58 \quad$ See CRPD, supra note 6 , arts $12,14,18$. 
rights and capabilities made by scholars such as Nobel Laureate Amartya Sen and Martha Nussbaum. ${ }^{59}$ It also contains an Optional Protocol which authorizes the Committee on the Rights of Persons with Disabilities to consider complaints by individuals against State Parties regarding perceived violations of the $C R P D$. Unfortunately, Canada has not ratified the Optional Protocol. ${ }^{60}$

In addition to this hybrid approach, the $C R P D$ also contains certain innovative provisions specifically aimed at the unique situation of people with disabilities such as articles 19 and 20. Article 19 stipulates that all people have a right to live and fully participate in the community. It specifically prohibits segregation of people with disabilities in living arrangements and mandates the provision of in-home support services to enable people with disabilities to live independently in the community. ${ }^{61}$ Article 20 requires State Parties to ensure the personal mobility of people with disabilities. This includes the provision of quality mobility devices at an affordable cost and appropriate training in their use. ${ }^{62}$ The fine grained specificity of this article is striking and speaks to the inclusion of certain socioeconomic standards within the required obligations of State Parties.

Each State Party that has ratified the CRPD must submit a comprehensive report on its progress in compliance with the Convention. These reports are reviewed by the Committee on the Rights of Persons with Disabilities, a body of approximately 12 disability rights experts from around the world. The Committee would then review the State Party's report and issue "concluding observations" evaluating the progress of the State Party in achieving the goals required by international law. Civil society organizations may produce shadow reports that critique the government's record on disability rights. ${ }^{63}$ While it is too early to fully assess the long-term impact of the $C R P D$, there are encouraging signs that State Parties are taking genuine steps to ensure compliance with the Convention. For instance, in the AsiaPacific region, New Zealand, the Republic of Korea, and the Cook Islands have all recently either adopted new disability rights legislation or made amendments to existing legislation to ensure requisite compliance with the CRPD. ${ }^{64}$

In evaluating the CRPD's potential for social transformation in the Canadian context, it is difficult to avoid the somewhat pedantic debate about how international treaty conventions

For a deeper discussion, see Michael Ashley Stein, "Disability Human Rights" (2007) 95:1 Calif L Rev 75; Sophie Mitra, “The Capability Approach and Disability” (2006) 16:4 J Disability Policy Studies 236 at 239-40; Martha C Nussbaum, Frontiers of Justice: Disability, Nationality, Species Membership (Cambridge: Harvard University Press, 2006).

60 Joëlle P Sala, "How the UN Convention on the Rights of Persons with Disabilities (CRPD) Might Be Used in Canadian Litigation" (Winnipeg: CCD, 2012), online: <www.ccdonline.ca/en/socialpolicy/ poverty-citizenship/legal-protections/crpd-in-canadian-litigation $>$. However, since the main text of this article was written, Canada has committed to signing the Optional Protocol by the end of 2017: Cerebral Palsy Association of British Columbia, "Canada Slated to Adopt the UN Optional Protocol by the End of 2017" (3 December 2016), online: <bccerebralpalsy.com/2016/12/canada-slated-to-adopt-the-unoptional-protocol-by-the-end-of-2017/>.

61 CRPD, supra note 6, art 19. See also John D Evans, "It Has Been a Long Time Coming" in Ines Bulić \& Camilla Parker, eds, Focus on Article 19 of the UN Convention on the Rights of Persons with Disabilities (London: European Coalition for Community Living, 2009) 17 at 17-19, online: $<$ www.nuigalway.ie/cdlp/documents/eeelfocusreport2009finalweb.pdf $>$.

62 CRPD, ibid, art 20.

63 Carole J Petersen, "The Convention on the Rights of Persons with Disabilities: Using International Law to Promote Social and Economic Development in the Asia Pacific" (2013) 35:2 Hawaii L Rev 821 at $822-23$.

$64 \quad$ Ibid at $840-41$ 
are incorporated in Canadian law. A full treatment of the doctrinal authorities is beyond the scope of this article; some brief remarks will suffice to illustrate the impact of the CRPD in a dualist country like Canada ${ }^{65}$ In short, when Canada ratified the CRPD in 2010 the Harper Government disappointingly did not enact implementing legislation and there remains no such legislation to date. Nevertheless, some aspects of the CRPD likely constitute customary international law and are therefore automatically Canadian domestic law unless contradictory legislation has been enacted. ${ }^{66}$ These would include some of the most basic provisions of the $C R P D$ such as the right to life in article 10 and the right to freedom from torture or cruel, inhuman, and degrading treatment in article $15 .^{67}$ Second, one may argue that existing legislation implicitly implements the CRPD in the absence of implementing legislation. Consequently, legislation would have to be reviewed for its compliance with the CRPD. While this is likely a challenging argument to make in the context of immigration law, it remains the case that this argument may be plausible in other domains. ${ }^{68}$

Third, Canadian statutes ought to be interpreted in a manner consistent with even unimplemented treaties. ${ }^{69}$ This was seen most notably in the Supreme Court's decision in Baker v. Canada (Minister of Citizenship and Immigration) ${ }^{70}$ an immigration case regarding the deportation of a parent with Canadian born children, with respect to the Convention of the Rights of the Child. ${ }^{71}$ Consequently, even if one takes the position that the CRPD is unimplemented, it may be possible to rely on it to interpret Canadian statutes in a manner consistent with the CRPD and the social model of disablement that animates the Convention. Finally, as seen in the recent expansive evolution of section 2(d) of the Charter in decisions such as Health Services ${ }^{72}$ and Saskatchewan Federation of Labour ${ }^{73}$ international human rights instruments may also influence domestic courts' understanding of the Charter. To date, there have only been a handful of cases in Canadian courts that have considered the $C R P D .{ }^{74}$ In Part IV, I turn to an ironic use of the CRPD. While this particular application may be disappointing to advocates of social justice, its use may nevertheless eventually bear fruit for immigrants with disabilities in future cases.

\section{The CaSe of Leobrera V. CANAda}

In Leobrera, the Federal Court, in a highly creative decision, held that the CRPD and the $C R C$ mandated adult children with disabilities to be treated as adults for the purposes of humanitarian and compassionate applications under section 25 of the IRPA. ${ }^{75}$ To be sure, innovations in law need not require engagement with international human rights instruments.

65

Unlike in a monist country, the dualist principle means there must be a domestic statute that acts as a conduit between Canadian society and the international convention. See Capital Cities Communications Inc $v$ Canadian Radio-Television Commission, [1978] 2 SCR 141.

Malhotra \& Hansen, supra note 7 at 84.

See CRPD, supra note 6, arts 10, 15.

Malhotra \& Hansen, supra note 7 at $84-88$.

Ibid at 88 .

[1999] 2 SCR 817.

CRC, supra note 10 .

Health Services and Support - Facilities Subsector Bargaining Assn v British Columbia, 2007 SCC 27, [2007] 2 SCR 391 (relying in part on ILO Conventions and other UN Treaties in finding British Columbia legislation in violation of section 2(d) of the Charter).

Saskatchewan Federation of Labour v Saskatchewan, 2015 SCC 4, [2015] 1 SCR 245 at paras 62-70. A Quicklaw search on 24 May 2016 found only eight cases.

Leobrera, supra note 9. Interestingly, counsel for the respondent is a lawyer with physical disabilities (personal communication from Martin Anderson). 
In the US, a majority of a panel in the 9th Circuit recently concluded that the decision of the Board of Immigration Appeals to exclude a petitioner with alcoholism from cancellation of removal or voluntary departure because he lacked good moral character solely because of his alcoholism violated the Equal Protection Clause. The Court found there was no rational basis to classify people with alcoholism as innately lacking good moral character. ${ }^{76}$ However, legal engagement with the $C R P D$, which the US Senate has yet to ratify, ${ }^{77}$ leads to a different set of policy questions and consequently is the focus of this Part.

Leobrera concerned the application of a twenty-three year old woman with intellectual disabilities from the Philippines. Her mother is a naturalized Canadian citizen who immigrated through the Skilled Worker Program. The daughter remained in the Philippines and was cared for by aging grandparents who were increasingly unable to continue to care for her. However, on the advice of an immigration consultant, the mother omitted the existence of her daughter with disabilities on her immigration application to avoid having her entire application rejected on medical inadmissibility grounds. ${ }^{78}$ The daughter subsequently filed a humanitarian and compassionate application. The visa officer concluded that the applicant was not a member of the Family Class because her mother did not report her existence when she applied for immigration. ${ }^{79}$ The officer did not apply the best interests of the child test with respect to the applicant. Instead, the officer applied the test only to the mother's younger daughter and concluded that the applicant would not face any unusual poverty or disadvantage as a result of her disability were she to remain in the Philippines. ${ }^{80}$

On judicial review, the Federal Court, in a decision by Justice Shore, allowed the applicant's appeal on the grounds that the officer wrongly removed relevant evidence about conditions in the Philippines from the applicant's file. ${ }^{81}$ However, for our purposes, the key discussion is the Court's analysis of the "best interests of the child" test in light of the relevant international human rights instruments, the CRC, and the CRPD and its associated legal reasoning. First, the Court concluded as a matter of statutory interpretation, the broad definition of a "dependent child" contained in the Immigration and Refugee Protection Regulations $^{82}$ only applied to the IRPR because section 2 of the IRPR delineated a boundary shielding the expansion of the definition beyond the IRPR. The definition consequently could not apply in the interpretation of section 25 of the IRPA. ${ }^{83}$ In reaching this conclusion, the Court chose to ignore numerous earlier cases which had allowed immigration officers to apply the "best interests of the child" test to families with children above the age of $18 .{ }^{84}$ Second, the Court applied the presumption of consistent expression principle to maintain that the fact that Parliament had used distinct terms ("dependent child" and "child") indicated that it intended that they be given different meanings by immigration officers. ${ }^{85}$ Third, the Court

\footnotetext{
Ledezma-Cosino v Lynch, 819 F (3d) 1070 (9th Cir 2016).

US International Council on Disabilities, "ADA Inspires Global Expansion of Disability Rights" (24 July 2015), online: <www.usicd.org/detail/news.cfm?news_id=1867\&id=178>.

Leobrera, supra note 9 at paras 8-12.

Ibid at paras $9-11$.

Ibid at paras $13-14$.

Ibid at paras 73-76.

$\mathrm{SOR} / 2002-227$, s $1[$ IRPR $]$.

Leobrera, supra note 9 at para 47.

See e.g. Ramsawak v. Canada (Minister of Citizenship \& Immigration), 2009 FC 636, 86 Imm LR (3d) 97 at paras 17-19 (accepting that the mere fact that a child is over 18 does not automatically relieve an officer from considering her best interests).

Leobrera, supra note 9 at paras 50-54.
} 
gave a robust interpretation to the importance of international treaties in interpreting ambiguous statutes. Having ruled that the term "dependent child" was ambiguous, the Court relied on article 23 of the $C R C$, relating to children with disabilities, and the Preamble to conclude that only children under eighteen should be entitled to the "best interests of the child" test. ${ }^{86}$ The Court also took judicial notice of the CRPD, specifically identifying article 7 devoted to children with disabilities. The Court concluded that its structure suggests that it intended to distinguish between adults and children. ${ }^{87}$ Consequently, the Court dismissed the applicant's arguments on this ground.

The tremendous irony of the Court's opinion in Leobrera is that it uses international human rights instruments such as the CRC and the CRPD to prevent adult children with disabilities from obtaining access to the more flexible "best interests of the child" test. This is, on its face, a setback with potentially dire consequences for immigrants with disabilities, one only averted in Leobrera because of other administrative law errors on the part of the visa officer. ${ }^{88}$ The "best interests of the child" is arguably more in keeping with the philosophical underpinning of the social model. At the same time, the reasoning behind a principle that distinguishes between adults and children and applying that principle to all individuals is cogent. Adults with disabilities do not remain eternal children.

However, when one thinks of the bigger picture, the application of international human rights instruments to domestic law holds tremendous promise for future litigants, both in immigration law and more broadly. Consequently, this analysis should not discourage counsel from making future applications of the CRPD. While the outcome here was undesirable and ironic, it is likely that future CRPD cases will strengthen and empower people with disabilities, including prospective immigrants. One potential tool for future litigation might be article 18 . This provision stipulates that people with disabilities are entitled to freedom of movement and nationality. ${ }^{89}$ Whether article 18 has the requisite teeth to challenge well-established immigration law principles that have a long history of exclusion remains to be seen. It may be an uphill battle, but it is one well worth undertaking.

\section{CONCLUding Remarks}

In this article, I have documented the historic exclusion of people with disabilities as immigrants. Relying on an ideology deeply suffused with notions of bodily perfection and compulsory productivity, immigrants with disabilities have too often been cast aside, stripped of their dignity and labelled medically inadmissible. This pattern of exclusion continues to this day as seen by the decision in Chesters. Nevertheless, decisions such as Leobrera hold out the possibility that immigration rules may be successfully challenged by international human rights instruments such as the CRPD. The promise of Leobrera is enormous if advocates for people with disabilities take on the challenge. 